\title{
PARENTALIDADE E CONJUGALIDADE: APARICOOES NO MOVIMENTO HOMOSSEXUAL
}

\author{
Anna Paula Uziel \\ Igor Torres Oliveira Ferreira* \\ Luciana Soares de Medeiros* \\ Carlos Alexandre de Oliveira Antonio** \\ Marcelo Tavares** \\ Mariana Borges de Moraes** \\ Rafael Andrade** \\ Universidade do Estado do Rio de Janeiro - Brasil \\ Renata Seixas Machado**** \\ Universidade Gama Filho - Brasil
}

Resumo: A temática da conjugalidade homossexual e da luta por direitos sexuais e reprodutivos divide o movimento homossexual e é instigante compreender as concepções que dão suporte às inflamadas defesas e posições contrárias ao "casamento gay" e/ou a luta por direitos sexuais e reprodutivos. O objetivo deste texto é entender como a conjugalidade e a parentalidade aparecem. Para tanto, um cuidadoso trabalho de pesquisa foi desenvolvido entre grupos homossexuais que demonstraram o conflito que ainda permeia esses assuntos polêmicos. Entre muitas outras coisas, observou-se que a parceria civil, embora não seja consenso sequer dentro do movimento, é vista como um tema aglutinador e que o lado obscuro da luta homossexual permanece ligado à violência e a homofobia, ainda presentes de forma marcante no Brasil.

Palavras-chave: conjugalidade, movimento homossexual, parceria civil, parentalidade.

* Mestrando(a) em Saúde Coletiva.

** Graduando(a) em Psicologia.

***A Aluna de Especialização em Teoria e Clínica Psicanalítica.

Horizontes Antropológicos, Porto Alegre, ano 12, n. 26, p. 203-227, jul./dez. 2006 


\begin{abstract}
Homosexual conjugality and the struggle for sexual and reproductive rights divides the homosexual movement and is quite a challenge to understand the conceptions that support the passionate defenses and the opposite positions to the 'gay marriage' and/or the sexual and reproductive rights. The purpose of the present paper is to understand how conjugality and parenthood are represented and accepted (or not). Careful research has been conducted among homosexual groups, showing that they bear conflicting views over such polemic issues. Among many other findings, it has been seen that one of the issues agreed by most of the researched people is the civil partnership and that the dark side of the homosexual struggle is against the violence and homophobia, still strongly pronounced in Brazil.
\end{abstract}

Keywords: civil partnership, conjugality, homosexual movement, parenthood.

\title{
Introduç̃o
}

Nos últimos anos, tem crescido o interesse de pesquisas sobre a homossexualidade, seja enfocando comportamentos, seja compreendendo valores ou investigando a consolidação de campos de luta e da própria constituição da identidade.

Este texto apresenta reflexões sobre os dados obtidos na pesquisa "Homossexualidade, Parentalidade e Grupos Homossexuais”. Trata-se de um projeto de pesquisa desencadeado com o final de uma investigação sobre conjugalidade e parentalidade homossexual, que teve como resultado a tese de doutorado intitulada Família e Homossexualidade: Novas Questões, Velhos Problemas (Uziel, 2002).

Durante a elaboração da tese, os breves contatos com militantes do movimento homossexual despertaram o interesse de investigar como os grupos homossexuais se colocam frente à questão da conjugalidade e da parentalidade homossexual.

Até os anos 1980, os grupos homossexuais que se constituíram eram sobretudo grupos de convivência, no início, e de afirmação homossexual, em seguida, distantes ainda do movimento por direitos. Temáticas consideradas como de primeira necessidade por integrantes dos grupos, momento de aparecimento, de criação de espaços voltados para as pessoas que, estigmatizadas, recolhidas ao máximo do espaço privado, não tinham ofertados espaços de sociabilidade, de encontro. Com o passar do tempo, os grupos passaram a ganhar visibilidade, especialmente com o início dos anos 1990 e a divulgação da Aids, 
que começou como um "câncer gay". Se por um lado era preciso se defender publicamente, por outro foi o "grupo" que mais rapidamente respondeu à epidemia com mudanças de atitude que misturaram, ao cenário de preconceito e repugnância, admiração, pena, compaixão. As discussões internas começam a atravessar as fronteiras e invadir a mídia, as pesquisas acadêmicas e sociais.

O objetivo deste texto é acompanhar os deslocamentos que as temáticas identificadas como prioridade sofreram, para entender como conjugalidade e parentalidade aparecem.

A temática da conjugalidade homossexual e da luta por direitos sexuais e reprodutivos divide o movimento e é instigante compreender as concepções que dão suporte às inflamadas defesas e posições contrárias ao "casamento gay" e/ou à luta por direitos sexuais e reprodutivos.

Foram entrevistadas as principais lideranças do movimento homossexual carioca, somando dez grupos. O objetivo deste artigo é apresentar e analisar como se deu a aparição dessas questões entre as reivindicações dos grupos organizados.

\section{Familia e homossexualidade em contexto}

Com o avanço da epidemia de HIV/Aids nos anos 1990, surgiram em diversos países do mundo projetos para a legalização da parceria entre pessoas do mesmo sexo. O teor desses projetos continua sendo objeto de controvérsias. Em alguns locais, essa parceria aproxima-se do estabelecimento de sociedade contratual, em outros é mais claramente identificado como conjugalidade ou família. Em geral, é grande a ênfase nas questões patrimoniais.

Em alguns países, a união civil homossexual foi reconhecida, tendo como momento de ruptura a legislação holandesa, ${ }^{1}$ que entrou em vigor em maio de 2001, permitindo e regulamentando não apenas o casamento entre pessoas do mesmo sexo, como a adoção de crianças por esses casais. Com essa lei, duas novidades são implementadas: o estatuto de casamento para homossexuais, até então privilégio das uniões heterossexuais, e o reconhecimento do direito à constituição de família, em função do estabelecimento do vínculo de filiação do

\footnotetext{
1 Após a Holanda, Bélgica, Canadá e Espanha concederam os mesmos direitos de casamento e adoção, com variações na forma como a sociedade e a legislação incorporaram essas mudanças.
}

Horizontes Antropológicos, Porto Alegre, ano 12, n. 26, p. 203-227, jul./dez. 2006 
casal. A conquista desse direito é o que parece gerar maior temor nos diversos países.

Judith Butler (2003) refere-se a uma pesquisa realizada na Califórnia em que $63 \%$ das pessoas aprovavam a idéia de que o casamento deveria significar a união entre um homem e uma mulher, calcado na compreensão de que esta união é legitimamente concedida pelo Estado. Essa afirmação insere-se em um universo mesclado entre essa legitimação estatal, a sanção da conjugalidade heterossexual e a bênção religiosa, sem que os sujeitos sejam capazes de identificar a que forças respondem. Nas entrelinhas, uma discussão sobre o que é e deve ser uma família, e quais são os limites toleráveis para a composição dessa instituição. É exatamente nesse contorno que a discussão se situa, visto ser esta a dificuldade central para a incorporação social e legal das uniões entre pessoas do mesmo sexo: integrar esse universo reconhecido como família.

Se a família aparece como a mais natural das categorias sociais, é porque funciona como esquema classificatório e princípio de construção do mundo social, bem como um valor a ser preservado. É constituída como entidade unida, integrada, unitária, estável, constante, indiferente à flutuação dos sentimentos individuais (Bourdieu, 1993).

A família nuclear, modelo inspirador da sociedade ocidental, é, cada vez mais, uma experiência minoritária. Segundo Foucault (1979, 1989), ela é um fenômeno recente e a conjugalidade hoje serve para estruturar a vida dos sujeitos. Nesse sentido, o debate sobre a pertinência, significados e conseqüências de se desejar constituir uma família legalmente aparece na literatura e nos discursos da militância homossexual. Se para alguns autores pleitear a constituição de família poderia significar submissão a um padrão heterossexual, como salienta Schiltz (1998), para outros é a possibilidade de reconhecimento e valorização de uma situação que já existe, embora seja constantemente colocada à margem da sociedade.

Com a epidemia de Aids, se por um lado a compreensão da síndrome como câncer gay contribuiu para maior segregação, por outro introduziu a homossexualidade no cenário social. A Aids punha em questão a noção de promiscuidade e apontava para a pluralidade de parceiros na estruturação de relações homossexuais, surpreendendo alguns com a existência de conjugalidade estável e monogâmica, padrões mais compatíveis com o ideal de família.

$\mathrm{Na}$ França, essa temática ganhou espaço. O debate francês sobre essas questões, que transbordava da Assembléia Nacional e invadia a imprensa no final dos anos 1990, atraiu sociólogos e psicanalistas e os cidadãos comuns. 
Na psicanálise, de um lado, Anatrella (2001) e Hamad (2002) têm posições contrárias à adoção por homossexuais, ainda que com argumentos distintos. O primeiro acusa o $\mathrm{Pacs}^{2}$ de se utilizar da relação de concubinato para escamotear a intenção de institucionalizar a relação homossexual. Ambos apostam na identificação entre homossexualidade e negação da diferença dos sexos, ponto de vista combatido por Tort (1999). Para Hamad, (2002, p. 40) não seria a homossexualidade o problema ou o impedimento para a concessão da adoção, mas o possível ódio ao outro sexo e a "renegação da diferença dos sexos”. A sociologia e a antropologia, os dois outros campos do saber que se apropriam dessa discussão, têm como eixo central, para defender ou negar esses direitos, a questão da diferença simbólica entre os sexos: se, por um lado, argumentam que admitir parceiros do mesmo sexo seria negar a diferença simbólica, por outro, os que defendem o direito ao reconhecimento da conjugalidade ou da família o fazem apostando na constituição de outras formas de parentesco. ${ }^{3}$

Esse debate, tão presente na academia e na militância francesas, não parece tão vivo nestas instâncias brasileiras. Discute-se, como veremos, o direito ao reconhecimento da conjugalidade com vistas a conquistas patrimoniais, previdenciárias, mas o direito à filiação, além de pouco tematizado, por diversas razões que podemos supor, não é sequer claro para boa parte da militância.

\section{0 movimento homossexual brasileiro e suas bandeiras}

A literatura costuma situar o final dos anos 1970 como a época do surgimento do que se convencionou chamar de movimento homossexual brasileiro, embora, desde o final da década anterior, boa parte das forças para que isso acontecesse já estivesse se fazendo presente (Green, 2000). O primeiro grupo organizado em defesa da homossexualidade foi o Grupo Somos de Afirmação Homossexual, de São Paulo. Seu principal objetivo era reunir homossexuais que estivessem interessados em assumir sua orientação sexual, encontrar seus pares, afirmar a homossexualidade (Câmara, 2002).

\footnotetext{
2 Pacto Civil de Solidariedade, que confere uma série de direitos a parceiros homo ou heterossexuais, visto que a legislação francesa anterior não reconhecia o concubinato.

3 Para maior detalhamento dos argumentos, ver Butler (2003).
} 
Quando a gente começou a estruturar foi justamente o Somos/SP que começou com aquela coisa de ter regimento interno, de ter estatuto, mesmo que não se registrasse, e aí o Rio de Janeiro copiou, tá? (Zenaide).

Trevisan (2000), ex-integrante do Somos, relata que as reuniões do grupo giravam em torno das experiências cotidianas dos participantes, além de dúvidas, problemas e projetos pessoais, tentando criar uma identidade enquanto grupo social. Em virtude das mal-sucedidas experiências de seus membros com partidos de esquerda, o Somos tinha uma preocupação em afastar-se desse tipo de militância. Através do “crescimento da consciência individual”, seu fundamento político era transformar a realidade começando não pelo outro, mas por eles próprios (Trevisan, 2000). Nesse sentido, a participação no grupo era fundamental para a auto-afirmação, a politização e a reivindicação coletiva de um reconhecimento efetivo pela sociedade como um todo.

Ter o direito de andar no meio da rua sem precisar estar levando porrada, sem precisar estar sendo presa por causa disso, porque... era uma época, quando começou a surgir grupos antigos como o "Turma OK”. (Úrsula).

Num segundo momento, marcado por um esvaziamento do movimento, ${ }^{4}$ os grupos mais atuantes parecem ter sido o Triângulo Rosa (do Rio de Janeiro), o Grupo Gay da Bahia (GGB) e o Atobá (do Rio de Janeiro). A partir de uma nova conjuntura, sem o controle da ditadura militar, mas com a chegada da Aids ao país, outras formas de ativismo foram produzidas, com outras demandas.

Segundo Câmara (2002, p. 36), o Triângulo Rosa "não discutia a discriminação interna de cada membro do grupo", nem outros assuntos pessoais de seus integrantes; no máximo, fatos ocorridos com outras pessoas. O enfoque era promover políticas públicas, leis e ações que pudessem ajudar a diminuir a discriminação contra os homossexuais, via partidos políticos, organizações da sociedade civil, OAB, Constituição Federal. Dessa forma, ainda que o movimento homossexual já tivesse abordado a temática dos direitos, seu significado não teve a importância que adquiriu com a atuação do grupo neste âmbito. Durante a Constituinte de 1988, o Triângulo Rosa articulou o movimento ho-

4 Uma discussão mais detalhada sobre os possíveis fatores que levaram a uma diminuição no número de grupos homossexuais no Brasil dos meados dos 1980 encontra-se em Facchini (2004).

Horizontes Antropológicos, Porto Alegre, ano 12, n. 26, p. 203-227, jul./dez. 2006 
mossexual para reivindicar a inclusão da expressão "orientação sexual"5 na Constituição Federal.

[...] se a discriminação por orientação sexual passasse a ser punida como crime, a associação entre homossexualidade e a criminalidade seria completamente revertida. (Câmara, 2002, p. 112).

No início da década de 1980, o GGB já havia coordenado uma campanha, com relativa participação dos grupos existentes, pela retirada da homossexualidade do Código de Classificação de Doenças do Inamps. ${ }^{6}$ Dessa ação, o grupo Somos/SP também participou, mas com uma atuação secundária, o que reforça a diferença entre o perfil dos dois grupos. Ainda nesse período, o grupo da Bahia fez a proposta, o encaminhamento e a campanha para que fosse criada uma lei que punisse a discriminação por “opção sexual”, o termo utilizado na época (Facchini, 2004).

Mesmo com as atividades focadas no combate à Aids, o grupo Atobá apresentou um estilo de militância semelhante ao dos grupos de seu tempo, citados acima.

Como num primeiro momento a síndrome incidiu diretamente sobre a população homossexual, com caráter de epidemia, - pelo menos era disso que se tinha notícia, à época -, fizeram-se necessárias ações que tivessem uma abrangência maior que a de um grupo homossexual. Ao perceberem isso, os integrantes do Atobá começaram a percorrer o "gueto”, informando a comunidade homossexual sobre as formas de contágio e prevenção, ao mesmo tempo em que cobravam do poder público respostas ao problema. Isso não significa que o Atobá, assim como o GGB e outros grupos da época, não mesclassem atividades de relatos pessoais e mobilizações em torno de atos e campanhas (Facchini, 2004), como muitos dos grupos entrevistados por nós fazem até hoje. Porém, o foco do ativismo, definitivamente, não era mais o mesmo da primeira fase do movimento.

\footnotetext{
5 Embora tal expressão possa soar “acusticamente” ruim nos dias atuais, houve uma série de confabulações na época para se chegar a esse termo como o mais adequado. Segundo Câmara (2002, p. 111), a intenção era que a expressão fosse incluída no artigo 153, § $1^{\circ}$, após a igualdade por "sexo". Contudo, apesar de todos os esforços, não se obteve sucesso. Essa inclusão explícita se deu posteriormente nas leis orgânicas de vários municípios e estados do país.

6 Código 302.0: homossexualidade como distúrbio, em 1981, para a categoria V62 - outras circunstâncias psicossociais -, em 1985.
} 
Portanto, estamos falando de uma diferença que remete a atuações políticas em dois níveis: o nível micropolítico, das experiências, em que se concentravam os ativistas da primeira fase do movimento, e o nível macropolítico, das representações, do contexto mais amplo, que preocupava mais os militantes da "segunda onda". A questão é que para alguns grupos dos meados dos 1980, especialmente o Triângulo Rosa, as "reuniões de reconhecimento" que o Somos fazia (MacRae, 1990), por exemplo, não tinham um caráter político. Talvez para os ativistas do segundo momento, assumir a homossexualidade não significasse mais militar, visto que a nova identidade homossexual já havia conquistado certa visibilidade com os grupos anteriores, estava consolidada e podia ser tomada por eles como algo natural. Era como se os novos militantes não precisassem mais perseguir diariamente o direito de se dizerem homossexuais.

Andrade (2002) destaca a precariedade da visibilidade, contrapondo essa idéia em seu estudo sobre a visibilidade gay. Para ele, o segmento homossexual ainda está submetido a um processo de invisibilização que facilita a difusão de imagens negativas que tornam as experiências homoeróticas atributos de identidade.

Os recém-criados programas estatais de combate à Aids começaram a financiar projetos de prevenção à epidemia coordenados pelos grupos, que puderam organizar-se melhor, muitos assumindo o estatuto legal de ONG. A luta contra a Aids passou a ocupar um lugar de destaque ainda maior entre as bandeiras do movimento e, a partir do que pudemos observar no contato com os grupos, provavelmente não perderá seu posto com facilidade, em função da dependência que estes passaram a ter das verbas oriundas do Ministério da Saúde para a continuidade de suas ações. A aproximação entre o movimento homossexual e o poder público, que já vinha acontecendo lentamente, estava selada.

No final dos anos 1980, com o crescimento dos casos de Aids e a demora do governo em produzir respostas à epidemia, o movimento homossexual voltou a crescer com o aparecimento de novos grupos para preencher esta lacuna, exigindo providências e tomando a frente em algumas ações. A fala de vários entrevistados destaca claramente o envolvimento do movimento na prevenção de DST/ Aids no momento de proliferação das ONGs/Aids no início dos anos 1990.

O Triângulo Rosa tinha dois dos seus líderes contra o investimento maciço na questão da prevenção à Aids, pois consideravam que isso era uma questão referente ao programa de saúde e que defender essa causa poderia apoiar a associação feita entre Aids e homossexualidade. 
A proposta peculiar ao Triangulo Rosa era o rompimento das fronteiras sociais estabelecidas pelos preconceitos - por isso a importância das reivindicações jurídicas -, nesse sentido, trabalhar com a prevenção da Aids significava, para o grupo, reforçar essas fronteiras. (Câmara, 2002, p. 69).

Nessa época, era evocada com destaque a noção de “grupos de risco”, que reforçava a idéia de guetos, aumentando o preconceito e a discriminação. O fim do jornal Lampião significou, para alguns, a desativação de certos grupos (Câmara, 2002, p. 43).

Em 1991, já circulava no Brasil, em escala nacional, o jornal Nós Por Exemplo. Seu objetivo era a prevenção à Aids, porém inovava, desenvolvendo um trabalho de prevenção junto ao público gay associado à construção da sua cidadania, então abalada pela epidemia. Em seu editorial de lançamento, ano 1, número 1, afirma:

Para NÓS POR EXEMPLO é vital que o homossexual brasileiro seja respeitado. E para que isto aconteça, a busca do conhecimento é indispensável. Refletir sobre a própria condição é iniciar o processo de auto-estima que é o único caminho para se fazer respeitar. (Andrade, 2002, f. 43).

Nesse período, houve uma maior articulação entre os grupos, formando de fato um movimento homossexual, o que pode ser percebido por uma maior regularidade na realização dos Encontros Brasileiros de Homossexuais (EBHO) - que, a partir de 1995, passam a ocorrer paralelamente aos encontros nacionais de homossexuais que trabalham com Aids -, pelas diversas iniciativas de formação de uma entidade nacional que agregasse os grupos do país -, o que acabou dando origem à Associação Brasileira de Gays, Lésbicas e Travestis (ABGLT) em 1995 - e pela realização da 17a Conferência Internacional da International Lesbian and Gay Association (Ilga) ${ }^{7}$ - uma ONG belga, de cará-

7 Ao final da Conferência, foi realizada uma passeata pelas ruas do Rio de Janeiro, o que influenciou o surgimento no Brasil da idéia da organização de manifestações de rua por ocasião das comemorações do Dia Internacional do Orgulho Gay (Facchini, 2004). Dois anos depois, esse evento foi batizado de Parada do Orgulho Gay e passou a ser realizado todos os anos em diversas cidades do Brasil, tornandose a principal manifestação pública do movimento pela defesa dos direitos dos homossexuais (Trevisan, 2000). Em 2004, havia 1,5 milhão de pessoas na Parada Gay de São Paulo.

Horizontes Antropológicos, Porto Alegre, ano 12, n. 26, p. 203-227, jul./dez. 2006 
ter internacional, que, à época da Conferência, contava com 450 grupos associados em mais de 60 países - no Rio de Janeiro, em 1995 (Facchini, 2004).

À frente desses movimentos estava o Grupo Arco Íris (GAI), objetivando dar maior visibilidade à temática da homossexualidade no contexto social. Essas articulações obrigavam um diálogo com o padrão heteronormativo, um embate político e discursivo, "sobre a importância das representações acerca das homossexualidades na construção das identidades gays e na construção das identidades do grupo" (Andrade, 2002, f. 12).

Aqui temos uma questão bastante importante e sutil. Para que tenha seus direitos civis reconhecidos, os homossexuais precisam tornar-se visíveis no espaço público. Em contrapartida, esse reconhecimento baseia-se na construção de uma identidade que contrapõe o padrão heteronormativo (normalidade), associando a homossexualidade aos campos da doença, desvio, pecado, submissão, crime (anormalidade). Segundo Andrade (2002, f. 25), as identidades sempre se contituem "em relação a”. Nesse sentido, assumir a homossexualidade seria, ao mesmo tempo, uma necessidade e uma dificuldade.

Entretanto, é curioso notar que, apesar de toda esta articulação dentro do movimento, o termo geral "homossexual" vai aos poucos sendo substituído. Segundo um dos entrevistados de Câmara (2002, p. 55) "o homossexual não existe, existem práticas homossexuais”.

Surgem então outras categorias, como, por exemplo, o "entendido" como novo sistema de classificação em oposição ao termo médico "homossexual”. No final da década de 1970 o movimento adota o termo "bicha". Mas era uma nova bicha que nada tinha a ver com o seu precursor.

É... naquela época a gente não falava gay nem lésbica, era viado, mariquinha, jiló, xuxu, qualquer coisa, qualquer fruta, qualquer animalzinho, menos gay, homossexual. Aí dos anos 1980 e pouco pra cá, se chamava de "entendido", ficava mais chique do que você chamando o outro de Maria-Homem, Maria-João, mulherzinha. O entendido foi nos anos 1980. [...] Não sei se pela aproximação das ONG's Aids... começou a ficar uma coisa mais globalizada, a gente sabia que o movimento lá fora se denominava gay e lésbica, e a gente passou a incorporar. Mas até então os encontros aqui no Brasil eram... encontro nacional de movimento homossexual, e as denominações eram essas, era "entendido", homossexual masculino ou feminino. Nem travesti nem transgênero não tinham suas reivindicações porque eram travesti, todos se consideravam homossexuais. Depois é que veio... "se tem gay, se tem lésbica, então tem que ter o travesti. Eu não me reconheço mais no gay, ou então não tô sendo... minha visibilidade não tá no gay, quero que o travesti tenha uma visibilidade também.” (Úrsula). 
Segundo Câmara (2002, p. 56):

“Gay” hoje é percebida - mais nos centros urbanos, e muito freqüentemente entre grupos mais jovens - como uma categoria cultural distinta. [...] "gay”, em outras palavras, representa mais que um ato sexual, como "homossexual" - mais que apenas um “clone”. Significa identidade e papel, mas também um sistema distinto de regras, normas, atitudes, e crenças sobre as quais a cultura dos homens gays é feita, uma cultura que sustenta as relações sociais do desejo pelo mesmo sexo.

Diante da exclusão das questões especificamente femininas da pauta do movimento se fez necessária a criação de uma outra categoria: a lésbica.

Segundo Andrade (2002), no início dos anos 1990 não se julgava importante separar homens e mulheres em relação a reivindicações ou problemáticas. Entendia-se que o inimigo era a norma heterossexual. Havia uma submissão do que pudesse ser considerado questão ou identidade lésbica à identidade gay. No entanto, um conselho de mulheres era uma prática difícil. Isso fica claro em uma das entrevistas feitas por Augusto Andrade para a sua tese, em 1994:

Culturalmente, nós mulheres, não temos a prática de reunião. As mulheres se reuniam para falar de filho, para falar de casa e para trocar receita... Os gays já sofrem todo um processo de discriminação, mas eles são homens, então é uma discriminação diferente porque eles têm o poder, eles têm o falo e a nossa sociedade é uma sociedade extremamente fálica... Não tinha nenhum atrativo para as mulheres. Era uma época em que a Aids, a gente ainda perdia muitas pessoas por conta da Aids e tudo era muito focado para as questões de cidadania dos direitos dos portadores do HIV. Era uma questão mais masculina. (Andrade, 2002, f. 31).

Dentro da própria categoria gay, novas nuanças começaram a ser evidenciadas: modelo gay-gay ou gay-macho como nova concepção de masculinidade. Proposta de masculinidade-masculinidade.

É possível perceber como a hegemonia de diversas formações discursivas constroem sentidos para o sujeito e o impedem de ocupar certos lugares, certas posições. E como no caso da homossexualidade produzem associações do tipo: viado, efeminação, prostituição, marginalidade.

Assim, da categoria homossexual, várias categorias começaram a se desdobrar: gay, lésbica e travesti, que hoje integram e ampliam a sigla GBLT. O próprio Encontro Brasileiro de Homossexuais (EBHO) passou a se chamar Encontro Brasileiro de Gays, Lésbicas e Travestis (EBGLT) em 1997. Ao mes- 
mo tempo em que se propunha uma maior unificação do movimento, tentava-se dar maior visibilidade a cada identidade coletiva que o compõe, ${ }^{8}$ com o objetivo de destacar as especificidades de cada segmento, provocando o surgimento de reivindicações particulares de cada um deles.

No século XXI, os grupos dão continuidade à história do movimento. Através das entrevistas com os principais ativistas homossexuais do Rio de Janeiro, pudemos constatar que em 2004 os temas mais apontados como bandeiras foram: prevenção de DST/Aids, ${ }^{9}$ elevação da auto-estima dos homossexuais, luta contra preconceito/discriminação/ violência, visibilidade e conquista de direitos via legislativo ou judiciário - como os ligados à questão da conjugalidade entre homossexuais. Entre os grupos de lésbicas, a violência entre companheiras lésbicas parece ser uma temática importante.

É interessante perceber como a forma atual de fazer militância convive com um tipo de ativismo característico da primeira fase do movimento. A luta atual pelo direito a uma lei que reconheça a união entre pessoas do mesmo sexo parece aglutinar a luta contra a discriminação, a elevação da auto-estima, o reconhecimento da relação afetiva, tudo isso no formato de um direito, que tem como pano de fundo a discussão sobre direitos humanos.

\section{Registro e reconhecimento legal da união entre pessoas do mesmo sexo}

O Projeto de Lei 1151/95, que disciplina a união civil entre pessoas do mesmo sexo, foi apresentado ao Congresso Nacional Brasileiro em 1995, pela então deputada Marta Suplicy (PT-SP). Na época, suscitou tamanha polêmica, provocando debates na mídia, manifestações de diversos segmentos sociais, articulações políticas de forças conservadoras para evitar a sua aprovação, que foi criada uma comissão especial para discuti-lo. Das 11 reuniões organizadas, nove foram destinadas a audiências públicas, com exposições de ativistas do movimento homossexual, ${ }^{10}$ representantes de comissões de direitos huma-

8 Esse fenômeno é melhor explorado por Facchini (2004).

9 Apesar de muitos grupos relatarem atividades de prevenção à DST/Aids, o que se observa, na grande maioria dos casos, são apenas ações voltadas para a Aids.

${ }^{10}$ Para um aprofundamento da questão, ver Mello (2005). 
nos, juristas, psiquiatras, psicólogos e líderes religiosos (Uziel, 1999). A partir desses encontros, o projeto original foi alterado, dando origem a um substitutivo que teve como relator o deputado Roberto Jefferson (PTB-RJ).

Tendo como meta a aprovação, o novo texto transformou a proposta inicial do projeto de lei. Do reconhecimento legal das uniões entre pessoas do mesmo sexo, que remetia à idéia de casamento, passou-se à parceria civil, que poderia ser confundida com a constituição de uma sociedade. Se a primeira corria o risco de fazer alusão ao desejo de constituição de família, a segunda lembrava uma garantia legal de direitos de sucessão, patrimoniais e previdenciários, deixando aparentemente de lado a existência de uma relação afetiva. Esse recurso era estratégico e reconhecido pelo movimento, o que fica evidenciado na fala desta militante.

Isto foi colocado da seguinte forma: nós não queremos a parceria civil, nos não queremos como tá, mas eu acho que pra gente ganhar alguma coisa além... dá pra começar desta forma. (Heliete).

Para que a dimensão de família fosse apagada, foi incluída no projeto a proibição expressa à adoção, tutela ou guarda de crianças em conjunto por duas pessoas do mesmo sexo. Tal interdição também afastaria o fantasma de que depois de adquirirem o direito de "casar”, os homossexuais fossem pleitear o direito de ter filhos. Dessa forma, o conceito de família sustentado pela Constituição Federal ${ }^{11}$ não sairia ferido pela aprovação do projeto.

Entretanto, todas as modificações que o projeto sofreu parecem não ter sido suficientes. O substitutivo tramita até hoje no Congresso, após inúmeras tentativas frustradas de aprová-lo, e novos projetos ainda mais distantes da proposta inicial surgem e disputam espaço no Congresso. Em todas as vezes que foi colocado em pauta de votação, acabou sendo estrategicamente retirado para que não fosse derrotado - o que obrigaria os interessados na aprovação da lei a ter que recomeçar todo o processo de construção do projeto.

\footnotetext{
${ }^{11}$ A Constituição Federal reconhece como entidade familiar apenas a união entre um homem e uma mulher ou a comunidade formada por qualquer dos pais e seus descendentes. Se por um lado não impõe mais o casamento, por outro ainda restringe à existência de dois sexos diferentes para o reconhecimento de um casal, ainda que alguns juristas façam valer a contradição legal existente e encontrem brechas na lei para considerar o par do mesmo sexo como entidade familiar.
}

Horizontes Antropológicos, Porto Alegre, ano 12, n. 26, p. 203-227, jul./dez. 2006 
O movimento homossexual não tem uma posição hegemônica em relação ao projeto, seja o original, seja o substitutivo, ou mesmo sobre sua pertinência. Um bom exemplo é a posição de Úrsula, dizendo que:

É uma bandeira. Importante, é? mas é importante para quem tem bens pra deixar. Diga-se de passagem, é uma bandeira meio elitista.

Fernando, um ativista de grupo gay, um dos primeiros a ser entrevistado, nos previne que

a maioria dos grupos [...], até por uma questão da sua baixa estima, acha que não tem que constar a questão da adoção, até porque tem uma visão de que o gay não vai cuidar bem da criança.

No entanto, em nenhuma das nossas entrevistas, tal postura atribuída à maior parte dos grupos mostrou-se evidente. Pelo contrário, chegamos a encontrar grupos que inclusive reivindicam um projeto de lei que inclua explicitamente a possibilidade de adoção por um casal de homossexuais. ${ }^{12}$

Há, entretanto, algumas lideranças que são a favor do projeto original, que, segundo elas, pelo menos deixa a questão da adoção em aberto. Esses militantes alegam que defender o substitutivo seria legitimar um retrocesso. Nas palavras de Danilo, um militante gay de grupo misto:

Hoje já conseguimos uma série de avanços do ponto de vista da justiça. No reconhecimento ao direito de adoção por casais homossexuais ${ }^{13}$ e no reconhecimento do direito à guarda de companheiros do mesmo sexo, de pais ou mães de crianças, quando falece e tal. O caso, por exemplo, da Maria Eugênia. ${ }^{14}$

\footnotetext{
${ }^{12}$ A fala de Fernando aponta para um certo desconhecimento pelo ativista da posição dos outros grupos sobre o tema. Isso remete a algo que foi se tornando claro para nós ao longo da convivência com os ativistas do Rio de Janeiro: a inexistência de um movimento homossexual articulado na cidade. As disputas de poder, espaço na mídia e destaque na história do movimento permitem apenas atuações isoladas de cada grupo, mas aparentemente articuladas em torno de iniciativas como o Centro de Referência Contra a Violência e Discriminação do Homossexual (CERCONVIDH), que abriga o Disque Defesa Homossexual (DDH), e o Fórum de ONG-Aids.

${ }^{13}$ Embora a lei ainda não permita a adoção de uma criança por um casal de homossexuais, já há compreensão jurídica de que existe brecha legal para isso. Recentemente, concedeu-se adoção a um casal, no Sul do país, em Porto Alegre, criando-se uma jurisprudência.

${ }^{14}$ Referência à companheira de Cássia Eller, que conseguiu a guarda definitiva de Chicão, filho da cantora.
} 
Então, por exemplo... tendo expressamente a proibição da adoção, na verdade, a gente tá dizendo que o que a justiça fez até agora tá errado. É na verdade legitimar um retrocesso, coisa que a gente já avançou na justiça. Pelo menos o da Marta, original, é omisso. Ele não inclui a proibição expressa da adoção, não fala nem que sim nem que não. Não entra no assunto dentro do projeto. Então isso pra gente é melhor. Porque aí a gente pode utilizar como jurisprudência as vitórias que estão sendo já conseguidas na justiça.

Contudo, a segurança que o texto legal nos fornece não pode ser comparada às reiteradas decisões dos tribunais, apesar da incontestável função positiva destas. Os casos de Aids com morte de parceiros, o abandono do doente por parte da família e a disputa de bens entre parentes e o parceiro fizeram com que o poder judiciário se antecipasse ao legislativo (Uziel, 1999). Ajustiça foi obrigada a posicionar-se de forma emergencial em relação a essas questões, criando jurisprudência, ${ }^{15}$ que vem garantindo as conquistas nesse âmbito até hoje. Entretanto, pode ser complicado ater-se a elas: uma jurisprudência é uma fonte de direito secundária, tendo a lei como fonte de direito primária. É a lei que obriga, interdita, disciplina; a jurisprudência, desde que conhecida, apenas orienta uma decisão que deve ser tomada com base na lei.

Por outro lado, um texto legal numa interpretação literal e conservadora pode trazer amarras nem sempre desejadas, como no caso das leis de união estável de 1994 e 1996, hoje incorporadas ao Novo Código Civil. Por essa legislação, o casal heterossexual passa a ter uma série de obrigações, mesmo que não as queira. Se a lei da união estável foi criada para proteger os direitos daqueles que não queriam se casar, acabou tornando-se uma armadilha, na medida em que concede menor poder de decisão aos sujeitos.

Não podemos deixar de citar os ativistas que defendem que leis desse tipo não são mais tão necessárias, apoiando-se em alternativas como o livro de registro de união estável entre homossexuais. O livro, originalmente criado pelo Grupo Gay da Bahia, pretende servir como documento legítimo para casais do mesmo sexo provarem junto ao INSS e à justiça que vivem uma relação estável, não proibida a eles por lei, e, portanto, podem requerer os mesmos benefí-

\footnotetext{
${ }^{15}$ Rios (2004) fez um mapeamento das decisões reiteradas dos tribunais brasileiros no que diz respeito a direitos sexuais, no qual constam as jurisprudências em relação a esse tema.
}

Horizontes Antropológicos, Porto Alegre, ano 12, n. 26, p. 203-227, jul./dez. 2006 
cios conjugais legais concedidos aos heterossexuais (Grupo Gay da Bahia, 2003). Segundo Ivone, liderança de grupo de lésbicas, o livro funciona assim:

você me traz todos os documentos que comprovem a sua união estável com aquela pessoa e estável você tem que tá com essa pessoa há mais de dois anos. Documento: conta conjunta, seguro de vida, compra de imóvel, tudo que você pode fazer junto com outra pessoa. Morar junto e pagar o aluguel, constar no nome do contrato o nome das duas pessoas. Conta de luz, por exemplo, a casa é minha, eu moro com você, então você vai botar a conta de luz no seu nome pra provar que você mora comigo. Porque tem gente, mora num barraco em cima do morro dos Cabritos, como é que eu vou provar que fulana mora comigo? Então é o quê? Declaração dos vizinhos assinada e reconhecido firma. Aí eu junto tudo isso, anexo tudo isso na folha do livro e a pessoa vem aqui e assina. Isso vale pro INSS, já é lei isso dentro do INSS. [...] A gente só cobra o preço do registro mesmo lá no cartório de ONGs, tá?

Como pudemos perceber, as respostas possíveis às demandas dos homossexuais relativas aos direitos de sucessão, patrimoniais e previdenciários são várias. No entanto, em função do desacordo em relação à melhor resposta, configuram-se em mais um ponto de divergência entre os grupos do movimento, o que ficou evidente nas análises das entrevistas. ${ }^{16}$ Nesse sentido, o livro pode tanto ajudar como atrapalhar a aprovação do projeto, uma vez que os deputados podem considerar que ele já é uma resposta eficaz ao problema. Resta acompanhar a movimentação da temática no Congresso.

De todo modo, é interessante perceber como as lideranças do movimento homossexual carioca tentam afastar a idéia do projeto, assim como seus relatores, da noção de casamento. Durante todas as entrevistas, fomos enfaticamente repreendidos por qualquer menção à palavra, o que sugere uma forte crença de que tal atitude facilitará a aprovação do projeto, apesar do caráter ambíguo que o PCR apresenta. A recusa ao nome "casamento” também se dá em função do reconhecimento de que seria uma submissão à heteronormatividade dominante.

Para Marta Suplicy, Roberto Jefferson e os militantes entrevistados, tal diferenciação se faz necessária, já que o casamento é entendido legal, moral e

\footnotetext{
${ }^{16}$ Mesmo com o movimento dividido, o tema da Parada do Orgulho Gay 2004 do Rio de Janeiro foi “União Civil Já!”
} 
religiosamente como uma instituição heterossexual. Uma mudança de status obrigaria a transformações sociais mais profundas (e demoradas) - que dificultariam a aprovação do projeto -, pelas quais as demandas emergenciais dos homossexuais não poderiam esperar. Assim, preocupam-se em deixar bem evidente que não pretendem instituir o casamento gay, mas a forma como o projeto está disposto traz grandes semelhanças com a referida instituição, deixando dúvidas em relação a isso (Uziel, 1999).

Parece ser estrategicamente conveniente para o movimento homossexual manter as semelhanças, já que há mais de 20 anos a legalização das "uniões homoafetivas" é uma demanda dos grupos homossexuais brasileiros, ${ }^{17}$ e nada nesse sentido foi conseguido até agora. E mais ainda: não há consenso sobre a questão.

Ainda que, nos contatos anteriores às entrevistas, tenhamos apresentado a parentalidade ${ }^{18}$ como o tema da pesquisa, a maioria das lideranças do movimento homossexual do Rio de Janeiro só colocou a temática como questão quando perguntada explicitamente ou ao falar dos projetos de lei da união civil ou da parceria civil, abordando a polêmica em torno da inclusão ou não da possibilidade de adoção por homossexuais na lei. O foco central da discussão permanece em torno do projeto inicialmente apresentado por Marta Suplicy.

\section{Sobre a parentalidade}

A família está em desordem, diz Elizabeth Roudinesco (2003). Hoje, cada vez mais, novos arranjos familiares se impõem à sociedade, permitindo uma certa desnaturalização do conceito de família. As relações de afeto cada vez mais se sobrepõem ao fator biológico. Entretanto, o discurso que ainda predomina no campo do direito, enquanto legitimador desses novos arranjos familia-

\footnotetext{
${ }^{17}$ Facchini (2004) relata, com base num documento do GGB, que, já em 1984, no II Encontro Brasileiro de Homossexuais (II EBHO), uma das deliberações aprovadas foi a legalização do “casamento gay".

${ }^{18}$ É importante destacar que a maior parte delas não conhecia o termo, o que se justifica em função da pouca usualidade do mesmo. "Parentalidade” é uma palavra cunhada do vocabulário francês, traduzida do original parentalité, com o intuito de evitar a generificação do termo, própria da língua portuguesa.
} 
res, é o da "normalidade”. E é nesse contexto que a homossexualidade aparece à parte da norma.

Quanto à parentalidade, esta cada vez mais aparece deslocada da exigência da conjugalidade, com respaldo legal, como dito anteriormente. A filiação deixou de estar subordinada à instituição do casamento, tendo a Constituição Federal de 1988 equiparado laços biológicos a laços sociais, tratando com igualdade de direitos os diversos tipos de filiação.

A literatura vigente aponta para as seguintes formas de filiação em relação aos homossexuais: filhos de relações sexuais anteriores, dentro ou fora de um contexto de conjugalidade; adoção por apenas um parceiro; utilização de novas tecnologias reprodutivas (inseminação artificial para as lésbicas e barriga de aluguel para gays) ou ainda co-parentalidade entre lésbicas e gays (Grossi, 2003).

Dentre as formas apontadas, uma parcela pouco significativa de nossos entrevistados deu ênfase à filiação de relações sexuais anteriores, diferindo do discurso de entrevistados ativistas com filhos. ${ }^{19} \mathrm{~A}$ reprodução assistida é citada, na grande maioria das vezes, apenas quando indagada, o que aponta para uma certa desconsideração em relação à essa técnica, em função de seu acesso restrito a uma pequena parte da população pelo alto custo financeiro envolvido no processo. Como não há no Brasil legislação sobre o tema, mas apenas uma resolução do Conselho de Medicina com força de lei, talvez possíveis candidatos temam a exclusão por parte dos médicos, que são os que detêm o poder de decisão sobre quem pode ter filhos através do uso da tecnologia.

A alternativa para ter um filho que mais se destacou em nossa pesquisa diz respeito à adoção, tanto por parte das lideranças gays quanto por parte das lideranças lésbicas.

Entretanto, um aspecto interessante a ressaltar é a forma com que as lideranças reproduzem de certa forma a distinção de gênero e a maneira com que os papéis parentais são distribuídos.

A sociedade em geral reforça a figura feminina dentro de um papel de cuidador/educador ao passo que cristaliza a figura masculina dentro de um papel de provedor (Silveira, 1998). Argumentos que respaldam tal premissa fazem referência à capacidade "inata” da mulher no que se refere ao cuidado com os filhos. Os próprios atributos que se buscam para identificar a capacidade de cuidar de uma criança são reforçados tradicionalmente como atributos do feminino.

${ }^{19}$ Pesquisa que está sendo desenvolvida no momento. 
Dentro da mesma linha de argumento biológico, o fato de ser mulher é tido como agente facilitador para que se constitua uma família monoparental. Estatisticamente é possível se comprovar a superioridade numérica de famílias monoparentais cuja figura central é a mãe (Uziel, 2002).

Ainda que a adoção seja o método mais abordado, também é vista com ressalvas por uma das militantes, trazendo um velho fantasma eugenista, cada vez mais atual, respaldado pelas garantias (ilusórias) que a biologia ofereceria. Nas palavras de Débora, militante de grupo de lésbicas:

Eu não [adotaria]... A questão até do pré-conceito, de que eu não sei quais as heranças genéticas que aquela criança traz nos seus genes. Mas eu posso saber quais as heranças que a minha criança, que o filho, que a filha que eu vou pôr no mundo vai ter, né? São pré-conceitos.

Mesmo a adoção sendo uma alternativa gratuita, que não inclui a busca de um parceiro ou de material genético, nada parece ser suficiente para que se evite a repetição do discurso do senso comum em relação à adoção.

Embora em termos de estratégia política a posição do movimento oscile entre a inclusão ou não da adoção no projeto de parceria civil, há um ideal de que as condições para que se adote uma criança sejam as mesmas para todos, independentemente da orientação sexual, o que nem sempre ocorre no âmbito jurídico. Por mais que pela lei a homossexualidade do futuro pai ou mãe não seja um fator impeditivo para a aquisição da habilitação para a adoção de uma criança, é a orientação sexual não-heterossexual do requerente - declarada ou atribuída pelos técnicos do judiciário - que acaba direcionando a análise desses processos.

Tal atribuição acerca da homossexualidade é muito mais evidente e estigmatizante quando se trata de um homem solteiro a requerer a adoção. Isso nos traz de volta à exultação do feminino e ao caráter "naturalista" da maternidade, que aparece então mais liberta de suspeitas na esfera da justiça (Uziel, 2002). Se por um lado fica pouco evidente a estranheza dos entrevistados com o desejo de paternidade sem maternidade, por outro o desejo da parentalidade não aparece como demanda de casal, mas individual. Chama a atenção, inclusive, o discurso de uma das entrevistadas, contrária à adoção por um casal do mesmo sexo. Não se opõe, no entanto, à convivência de criança com o/a parceiro/a do pai/mãe. 
Embora não apareça como questão central, nem tampouco com uma relevância destacável nos grupos, a reivindicação pela parentalidade aparece, quando provocada, como questões privadas que são levadas ao grupo para que se consiga orientação legal em relação à disputa de guarda nos casos de divórcio ou do processo de adoção. Mesmo porque a adoção por homossexuais é uma condição que já se faz evidente no cenário atual, estando pendentes apenas questões de reconhecimento legal, quando se trata de casal. Tal falta de reconhecimento talvez venha a favorecer as práticas de adoção "à brasileira” em detrimento da adoção "legal”, que pudemos verificar no decorrer das entrevistas.

Sara, ativista de grupo de lésbicas, relata que seu grupo já fez reuniões específicas com a temática da parentalidade, onde estiveram presentes lésbicas que são mães. Nelson, ativista gay de grupo misto, nos contou que seu grupo está empenhado em realizar um trabalho dirigido a pais de homossexuais, a partir de uma demanda dos próprios, interessados em, nas palavras dele, "querer compreender melhor o seu filho e em como tratar o seu filho". Seu grupo tem a intenção de montar oficinas dirigidas à família e aos pais de homossexuais e, a partir daí, realizar reuniões específicas sobre o tema.

Segundo os entrevistados é comum chegarem aos grupos demandas relativas à parentalidade, para as quais fornecem o suporte necessário, mas não possuem uma reivindicação de ordem mais ampla para esse tema, que não chega a se transformar em uma causa. Alguns grupos acham que a questão não se torna uma reivindicação pública exatamente porque os homossexuais a restringem ao âmbito privado, numa tentativa de se protegerem e de protegerem seus filhos do preconceito da sociedade. Dessa forma, para eles, sem o engajamento das pessoas que têm a vivência dessa questão, a causa não consegue ganhar corpo apenas com a atuação dos ativistas que reivindicam o direito à parentalidade por uma questão política, por vivência teórica e/ou por compreender que é uma conquista importante. Outros grupos parecem tratar a temática como uma questão de âmbito privado e que, portanto, não teria motivo para passar ao nível público.

Tal fato nos suscita reflexões, uma vez que há uma implicação pessoal constante de grande parte de nossos entrevistados em projetos possíveis ou já concretizados de parentalidade, embora essa não seja uma questão que deva ser levantada como uma bandeira, pelo menos por enquanto. De fato, a maior parte das lideranças entrevistadas destacam em suas vidas privadas questões no que diz respeito à adoção, à guarda de filhos de relações heterossexuais anteriores e até à possibilidade de reprodução assistida, o que suscita reflexões 
sobre a pertinência de se restringir a parentalidade a um campo privado ao invés do público, fazendo com que esta pareça desprovida de caráter político.

Nesse contexto, a atuação militante dos grupos parece estar mais ligada a “pequenas” batalhas no campo judicial, como nos diz Nelson:

Nós procuramos os meios jurídicos. Você quer adotar uma criança. Você tem casa própria? Tem? Então tem. Você tem uma renda acima de tanto? Tem? Tem. Tem plano de saúde? Tem. Então, o grupo X vai comprar a tua briga. Não tem por que você ser rejeitado. Porque nós partimos desse princípio: a única coisa que podem nos cobrar é que nós tenhamos a mesma estrutura, digo, financeira do heterossexual. Não moral. Não moral. [...] "Ah não, porque moralmente não é legal.” Aí a briga é nossa. Agora, se você é um cara que tá desempregado, você vai ser desqualificado por isso, tudo bem. Se você for desqualificado porque você não tem uma estrutura financeira pra manter essa criança, o grupo $\mathrm{X}$ vai achar que a lei tá certa e pronto.

Danilo, ativista gay de grupo misto, defende que, num primeiro momento, é estrategicamente interessante manter a luta nesse âmbito, como se brigar por direitos na justiça fosse um primeiro passo importante para dar visibilidade às demandas da comunidade homossexual:

[...] ao mesmo tempo que você tem as bandeiras gerais, de luta, você também tem que construir, até pra poder fortalecer e respaldar essa luta geral, [...] o que eu chamo de acúmulo de força pra fortalecer essa própria luta geral. Então, à medida que você mostra que tem demanda de pessoas por guarda, por adoção, por pensão, por não sei o quê, você tá mostrando que você não tá lutando por um direito pra alienígenas, extraterrestres. Tá lutando por um direito pra pessoas que têm realmente essas necessidades.

Entretanto, existem outras questões envolvidas nesse aspecto. Para algumas lideranças, partindo do princípio de que nem o mínimo em termos de garantias foi conseguido, antes da parentalidade, haveria outras conquistas mais básicas pelas quais lutar. Até porque, segundo esses ativistas, a sociedade precisa estar preparada para receber as reivindicações dos grupos, pois, caso contrário, elas não serão acatadas e, nesse caso, não teria valido a pena lutar por elas no plano macro.

Parece haver no movimento homossexual uma hierarquia de bandeiras, organizadas segundo uma lógica da miséria, que defenderia a conquista do 
básico para se pensar no “luxo”. Um trecho da entrevista de Nelson evidencia estas considerações.

[...] Eu acho que a gente não deve brigar por essa causa. Eu acho que tem que ter o direito sim. [...] Mas eu acho que não é uma bandeira legal, porque você tem [...] tantos degraus ainda aqui pra subir e você quer pisar naquele que tá lá em cima, é complicado. Você acaba causando impacto com a hipocrisia da sociedade e a briga fica mais difícil. [...] No dia que você puder segurar a mão do seu companheiro, dar um beijo no rosto dele e não ser olhado de cara feia, lá na frente, você vai poder adotar uma criança e não ter nenhum tipo de discriminação, nenhum tipo de preconceito por isso.

No entanto, para Danilo, liderança gay de grupo misto, não se trata de uma hierarquia, mas de uma priorização de estratégias de reivindicações no plano macropolítico, em termos de mobilização da militância para que leis sejam aprovadas no congresso. Mas hierarquia e priorização não são palavras muito distantes semanticamente. Isso não quer dizer que os grupos ignorem outras demandas de defesa dos direitos dos homossexuais que surjam no cotidiano e não sejam bandeiras públicas. Nesses casos, atuam para dar-lhes uma resposta, ocupando outras frentes de luta, como esclarece Danilo:

[...] não é uma questão de excluir um tema, mas de analisar politicamente qual a estratégia, o que nós vamos priorizar, que estratégia vamos construir pra que esse projeto seja aprovado. Aí é você pensar estratégias de pressão política, de incidência política, de monitoramento, de articulação, de lobby, [...] O que nós deliberamos no último encontro, que a prioridade nossa nos próximos três anos é o projeto de união civil; dois, a questão da discriminação por orientação sexual, seja emenda constitucional, seja a inclusão da orientação sexual na lei anti-racismo, ou... em terceiro, a questão também da demanda dos transgêneros, que é reconhecimento de documentação [...] Tem outras coisas importantes? Tem. A questão da escola, a questão do homossexual nas forças armadas... Mas aí, como a gente prioriza... Mas não significa que no dia-a-dia a gente não deva estar falando desses temas também. E estar dando visibilidade pra que esses temas aconteçam [...] Enquanto a união civil não rola lá, eu não vou ficar parado sem fazer nada.

Parece que duas questões distintas estão postas em pauta: a prioridade em termos de reivindicações e as considerações em relação ao que pode ser entendido como bandeiras de luta. As temáticas que ocupam a pauta do mo- 
vimento homossexual parecem expressar interesses mais hegemônicos, bem como especificidades que apenas um movimento social poderia mobilizar, como podemos notar na fala desse militante. Questões referentes à documentação de transexuais e travestis, que têm implicações no seu reconhecimento legal e na construção de sua cidadania, embora pertençam a uma parcela do movimento numericamente menos significante, parecem garantir espaço.

\section{Algumas consideracõos finais}

A partir da análise do discurso de lideranças do movimento homossexual carioca, é possível supor que reconhecimento de parceria e parentalidade não são bandeiras essenciais, ainda que as duas tenham importância e destaque muito distintos.

A parceria civil, embora não seja consenso sequer dentro do movimento, é vista como tema aglutinador, que deve ser tomado como questão de ordem pública. Não é à toa que foi eleita recentemente como tema de paradas do orgulho gay. Mesmo assim, não aparece, no discurso dos entrevistados, como mais relevante. É certamente uma temática que inclui o movimento homossexual na ordem do dia, que desperta a atenção da população, gerando as reações que variam desde compaixão, tolerância até ódio, repugnância, passando também por um reconhecimento, cada vez maior, dos direitos plenos de cidadania que são negados a esse grupo.

No entanto, as preocupações com a exterminação da violência, da homofobia, têm aparecido ainda como bandeira que mais mobiliza a militância. O próprio caminho que o governo federal tomou, com o apoio da militância, implementando o programa Brasil sem Homofobia demonstra a prioridade dada a essa questão. Ao invés de investir em um caminho de conquista de direitos pelo afirmativo, a opção foi por uma postura de se combater o "negativo".

Parece imperar, como dissemos anteriormente, a "lógica da miséria". As possíveis bandeiras são escalonadas em um entendimento que apenas quando for possível ter os direitos básicos garantidos será possível reivindicar direitos semelhantes aos dos heterossexuais. Nesse sentido, a parentalidade está longe de aparecer como reivindicação. Permanece tratada quando convocada, quando individualmente é solicitada uma assessoria jurídica ou informações sobre como adotar, direitos sobre guarda, etc.

Os grupos não ignoram a questão da parentalidade, mas esta não se apresenta como uma bandeira para o movimento, pelo menos enquanto a lógica da 
hierarquia prevalecer e outros temas mostrarem-se mais básicos, emergenciais ou estratégicos e/ou enquanto a parentalidade for entendida como uma questão individual e não uma reivindicação coletiva, de igualdade de direitos.

Nas entrevistas, as lideranças mostraram que seus grupos têm desenvolvido ações relativas a questões ligadas a essa temática, que, segundo eles, é importante por propor uma rediscussão do modelo familiar burguês, que não é mais o hegemônico. É importante ressaltar que, mesmo desconhecendo o debate psicanalítico e sociológico francês, reproduz-se o discurso do risco da falta do outro sexo entre os militantes, e muitos deles não estão convictos sobre a propriedade do direito ao exercício da parentalidade por pessoas do mesmo sexo.

Os preconceitos contra a adoção, a reprodução do modelo de família nuclear atravessam o discurso dos militantes que não problematizam o modelo de família, no máximo ousam reivindicar direitos semelhantes, ainda sem consenso nem muita convicção. De onde se espera o diferente, muitas vezes vem o mesmo.

\section{Referências}

ANATRELLA, T. La différence interdite. Paris: Flammarion, 2001.

ANDRADE, Augusto José de Abreu. Visibilidade gay, cotidiano e mídia: Grupo Arco-Íris: consolidação de uma estratégia: um estudo de caso. Dissertação (Mestrado em Comunicação)-Faculdade de Comunicação, Universidade de Brasília, Brasília, 2002.

BOURDIEU, P. À propos de la famille comme catégorie réalisée. Actes de la Recherche en Sciences Sociales, n. 100, p. 32-36, décembre 1993.

BUTLER, J. O parentesco é sempre tido como heterossexual? Cadernos Pagu, n. 21, p. 219-260, 2003.

CÂMARA, C. Cidadania e orientação sexual: a trajetória do grupo Triângulo Rosa. Rio de Janeiro: Academia Avançada, 2002.

FACCHINI, R. Sopa de letrinhas?: movimento homossexual e produção de identidades coletivas nos anos 90. Rio de Janeiro: Garamond, 2004.

FOUCAULT, M. A política de saúde no século XVIII. In: FOUCAULT, M. Microfísica do poder. Rio de Janeiro: Graal, 1979. p. 193-207. 
FOUCAULT, M. História da sexualidade 1: a vontade de saber. Rio de Janeiro: Graal, 1989.

GREEN, J. N. Além do carnaval: a homossexualidade masculina no Brasil do século XX. São Paulo: Unesp, 2000.

GROSSI, M. P. Gênero e parentesco: famílias gays e lésbicas no Brasi”. Cadernos Pagu, n. 21, p. 261-280, 2003.

GRUPO GAY DA BAHIA. 2003. Disponível em: <http://www. ggb. org. br> Acesso em: 5 maio 2004.

HAMAD, N. A criança adotiva. Rio de Janeiro: Companhia de Freud, 2002. MACRAE, E. A construção da igualdade: identidade sexual e política no Brasil da "abertura”. Campinas: Editora da Unicamp, 1990.

MELLO, L. Novas famílias. Rio de Janeiro: Garamond, 2005.

RIOS, R. R. Diagnóstico sobre jurisprudências em direitos sexuais, 2004. Mimeografado.

ROUDINESCO, E. A família em desordem. Rio de Janeiro: Jorge Zahar, 2003.

SCHILTZ, M. Un ordinaire insolite: le couple homosexuel. Actes de la Recherche en Sciences Sociales, n. 125, p. 30-43, décembre 1998.

SILVEIRA, P. Exercício da paternidade. Porto Alegre: Artes Médicas, 1998.

TORT, M. Homophobies psychanalytiques. Le Monde, Paris, p. 9, 15 oct. 1999.

TREVISAN, J. S. A manipulação da homossexualidade liberada. In: TREVISAN, J. S. Devassos no paraíso: a homossexualidade no Brasil, da colônia à atualidade. 4. ed. revista e ampliada. Rio de Janeiro: Reccord, 2000. p. 333-385.

UZIEL, A. P. Reflexões sobre a parceria civil registrada no Brasil. Sexualidade, Gênero e Sociedade, Rio de Janeiro: IMS: Uerj, n. 11, p. 1, 8-11, julho 1999.

UZIEL, A. P. Família e homossexualidade: velhas questões, novos problemas. Tese (Doutorado em Ciências Sociais)-IFCH, Universidade Estadual de Campinas, Campinas, 2002. 